\title{
Seasonal Variability of Coastal Water Quality in Bay of Bengal and Palk Strait, Tamilnadu, Southeast Coast of India
}

\author{
Viswanathan Srinivasan, Usha Natesan* and Anitha Parthasarathy \\ Centre for Water Resources; Anna University; Chennai
}

\begin{abstract}
The aim of this work was to study the physicochemical parameters of water quality collected from 12 sampling stations from Topputhurai to Muthupet in Vedaranyam located on the southeast coast of India from January to December 2008. Results showed that the DO and nutrients were the maximum in the Bay of Bengal during the monsoon period. High concentration of the nutrients in summer season was obtained near the Muthupet mangroves compared to the Palk Strait, which showed that this acted as a source of nutrients to the adjacent coastal waters. Low concentrations of the nutrients observed in the monsoon could be attributed to the terrestrial runoff from Muthupet lagoon. The physicochemical characteristics of coastal waters between the Point Calimere and Muthupet could be used as a baseline data for the monitoring, conservation and management of Point Calimere Wildlife and Bird sanctuary, Great Vedaranyam swamp and Muthupet mangrove ecosystem.
\end{abstract}

Key words: coastal zone, physico-chemistry of water, nutrients, Vedaranyam, Bay of Bengal, Palk Strait

\section{INTRODUCTION}

Coastal waters often receive huge urban sewage inputs due to the high density of inhabitants in the coastal areas (Scialabba 1998). Land ocean interactions in the coastal zone are currently the focus of much regional and global research aiming to quantify and determine the changes and effects of human usage on the coastal environments (Kress et al. 2002). Land-derived materials are modified and transferred in the coastal and shelf region via various processes/mechanisms, which in turn regulate the flux of continental materials, both natural and anthropogenic, to the ocean (Martin and Windom 1991). Coastal zone also provides an important buffer zone and filtering system for the coastal ecosystem. All these components are in a fragile balance controlled by the physical and biological processes, which can be easily upset by natural or human induced perturbations (Viles and Spencer 1995). The coastal environments are exceptionally diverse and productive, particularly in the shallow water tropical regions. Coastal wetlands such as salt marshes, estuaries, and backwaters have high productivity, but their structure and function are altered through human inputs of materials in both soluble and particulate forms. These ecosystems not only protect the coast from the natural calamities but also provide livelihood security to nearly high number of local population.

Mangrove forests are considered to be highly productive tropical ecosystems (Clough 1992). Mangroves are ecologically sensitive, provide physical protection to the communities, and more importantly, are believed to play a major role in supporting the tropical estuarine and coastal food webs (Alongi and Christoffersen 1992). At present, the coastal environments are highly disturbed and very much threatened, encountering problems such as the pollution, mangrove deforestation, siltation, erosion, flooding and other

*Author for correspondence: u_natesan@yahoo.com 
development activities due to over-expanding human settlements. Water quality obviously plays a critical role in this relationship (Ntengwe 2006), as it is a key to the maintenance of a well balanced environment. Physicochemical events in the coastal waters and their relationships reveal that these do not occur independently but are linked with each-other (Iyer et al. 2003). Nutrient enrichment leads to the eutrophication of a large number of coastal zones (Cloern 2001) with a concomitant increase in the harmful algal bloom frequency. The present study was taken up to understand the prevailing condition of the water quality and the impact of the anthropogenic input on this ecosystem. A significant variation in the properties of the Kalpakkam coastal waters, eastern part of India, was observed during the event of southwest to northeast monsoon transition (Satpathy et al. 2010).

\section{STUDY AREA}

Great Vedaranyam swamp spread over 630 sq.km. is a large coastal wetland complex, located between $79^{\circ} 25^{\prime}$ and $79^{\circ} 52^{\prime} \mathrm{E}$ longitude and $10^{\circ}$ $17^{\prime}$ and $10^{\circ} 22^{\prime} \mathrm{N}$ latitude, situated at the Coromandel coast in southern end of Nagapattinam District. Great Vedaranyam swamp is broadly classified into two parts, which are connected during rainy season. Northern boundary is covered with Point Calimere forests and bounded by the Bay of Bengal in the east. Mangroves and Muthupet lagoon form the western part of Vedaranyam (Fig. 1). Wetland forms the major refuge for migratory and resident birds. Point Calimere wildlife and bird sanctuary including the Great Vedaranyam Swamp and Talaignayar Reserve Forest has been declared as a Ramsar site in 2002.

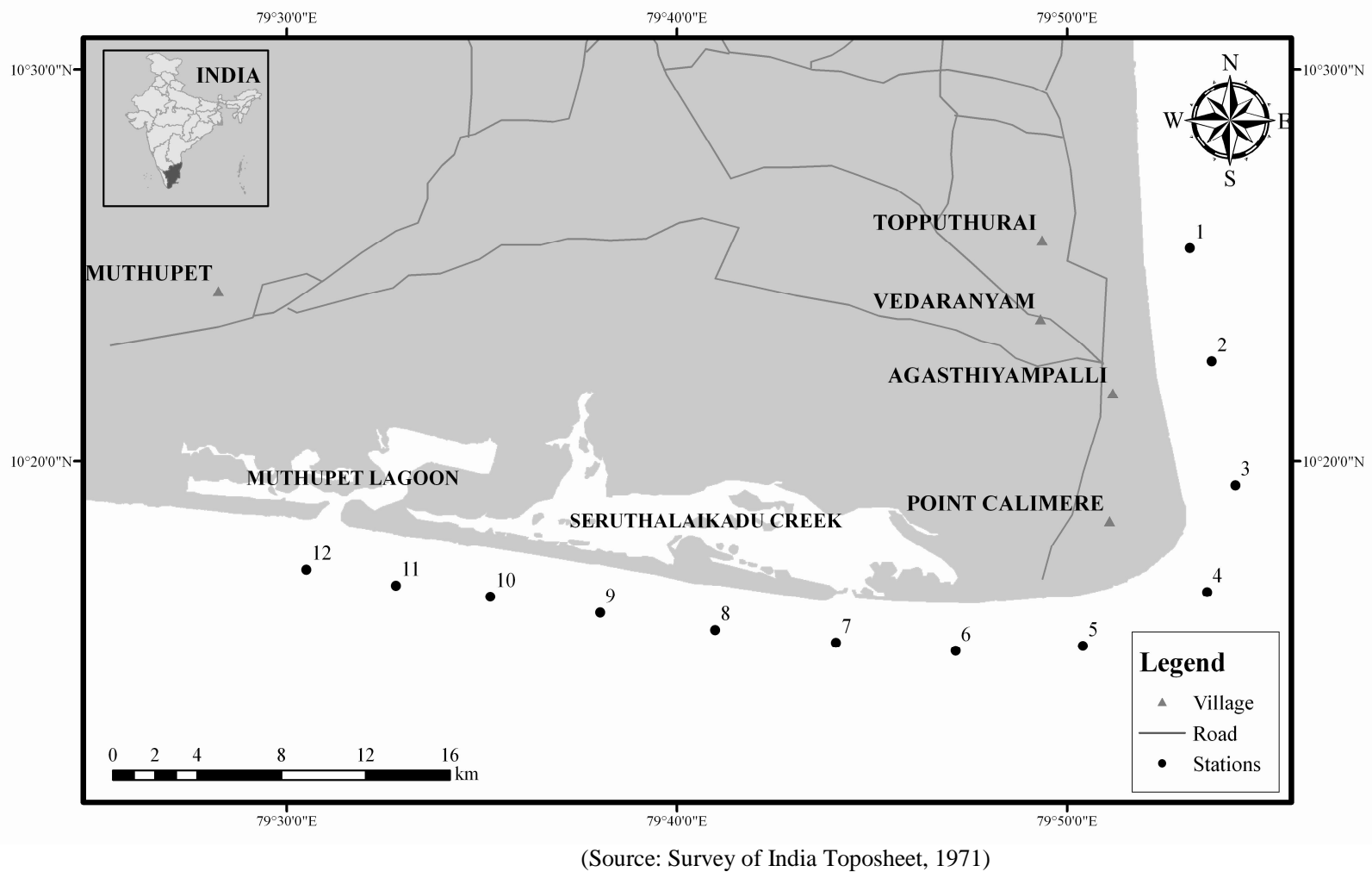

Figure 1 - Study area map with sampling locations.

Muthupet Mangrove Forest is located at the southern end of the Cauvery delta, covering an area of approximately 6803 ha, of which only $4 \%$ is occupied by the well-grown mangroves. Thick mangroves are bordered besides the Muthupet lagoon along the shore and extend upto Point Calimere. Healthy mangroves occupy only $15 \%$ of the total area (Selvam et al. 2002). The Muthupet mangrove forest is characterized by the presence of Avicennia marina, Aegiceras corniculatum, Excocaria agallocha, Acanthus ilicifolius, Rhizophora mucronatoa and Lumnitzera racemosa. Avicennia marina is the dominant (95\%) mangrove species present in the great 
Vedaranyam swamp. Olive Ridley Turtle is an important endangered species present in the coastal areas of Vedaranyam.

About 3.2 MLD of effluents generated from the chemical industries, salt industries and tobacco processing factories is directly discharged into the sea. Few small aquaculture farms are also present in this area. Canal fishing, the traditional fishing method is being practiced in Vedaranyam. People belonging to 26 coastal hamlets of Vedaranyam with a total population of about 35900 depend on the fishery and forestry resources of Muthupet.

The purpose of this study was to understand the seasonal and spatial variations in the physicochemical parameters of the coastal water along Vedaranyam. As several developmental activities such as dredging, construction of ports for the Sethusamudram ship canal project in the Palk Strait are planned, there is a need to study the coastal waters of Vedaranyam prior to those developments. This could serve as a baseline data to understand the changes on the marine protected area.

\section{MATERIALS AND METHODS}

\section{Sample collection and analysis}

The study area comprised of Point Calimere forests and Muthupet lagoon dominated by the mangroves. Sea water samples were collected from 12 stations, covering $60 \mathrm{~km}$ coastal stretch. Stations 1 to 3 lied near the fishing villages located along the East coast of Tamilnadu in the Bay of Bengal. Station 4 was located at the transition zone between the Bay of Bengal and Palk Strait while the remaining stations were located along the Palk Strait in the fringes of mangroves and swampy coast. Post monsoon denoted the period between January and March. April and May represented the summer season. The period between June and September was the southwest monsoon. October to December was considered as the northeast monsoon season. The water samples were collected every month on new moon day at high tide from January to December 2008. Polypropylene bottles precleaned with $1: 1$ dilute hydrochloric acid and rinsed with Milli Q water and dried were used for the collection of the samples. Temperature, $\mathrm{pH}$, salinity and dissolved oxygen (DO) were measured on-site using the multiparameter instrument (3400i WTW,
Germany). Samples were preserved in ice during the collection till transportation to the laboratory. Samples were immediately filtered using $0.45 \mu \mathrm{m}$ Millipore membrane filter paper and analyzed for various physicochemical and biological parameters, viz., nutrients such as inorganic phosphate $\left(\mathrm{PO}_{4}{ }^{3-}\right)$, nitrite $\left(\mathrm{NO}_{2}-\mathrm{N}\right)$, nitrate $\left(\mathrm{NO}_{3-}\right.$ $\mathrm{N})$, Ammonia $\left(\mathrm{NH}_{3}-\mathrm{N}\right)$, silicate $(\mathrm{Si})$, suspended particulate matter (SPM) and Chlorophyll a (Chla), following the standard methods (Grasshoff et al. 1983; APHA 1995). Nutrients were measured by the colorimetric methods. Chlorophyll a was extracted in 90\% acetone and measured spectrophotometrically (Spectronic 20 GENESYS, Germany) following Parsons et al. (1984).

\section{RESULTS AND DISCUSSION}

\section{Rainfall and Atmospheric Temperature}

Rainfall and atmospheric temperature data were collected from the Indian Meteorological Department (IMD). The rainfall occurrence reduced from the northeast monsoon, followed by the summer, southwest monsoon and postmonsoon. The maximum rainfall of $1245 \mathrm{~mm}$ and minimum $17 \mathrm{~mm}$ were recorded in the northeast and post-monsoon seasons, respectively in 2008 (Fig. 2). The northeast monsoon resulted in an inundation of the study area, resulting in higher volume of fresh water discharge and transported the terrigenous deposits into the coastal waters. At Muthupet, the air temperature was mainly influenced by the seasonal and climatic variation, including the wind speed. The highest $\left(36.2^{\circ} \mathrm{C}\right)$ and lowest $\left(25.6^{\circ} \mathrm{C}\right)$ temperatures were noticed during the summer and northeast monsoon, respectively.

\section{pH}

Figure 3 shows the variations of water quality for different seasons. The $\mathrm{pH}$ ranged from 7.8 to 8.3 during the study period, showing no remarkable variations. The elevated $\mathrm{pH}$ level in the summer might be due to the water evaporation and high salt accumulation in Palk Strait. The higher phytoplankton production and greater photosynthetic activity could increase the $\mathrm{pH}$ due to bicarbonate degeneration by the carbonic anhydrase. This occurred concurrently along with the photosynthesis to facilitate carbon production (Rutner 1966). Decrease in the $\mathrm{pH}$ during the northeast monsoon might be due to rainfall, land 
runoff and prevailing low salinity conditions. A positive correlation (0.58) with Chl-a observed during the summer could be attributed to the phytoplankton growth, which increased the Chl-a concentration.

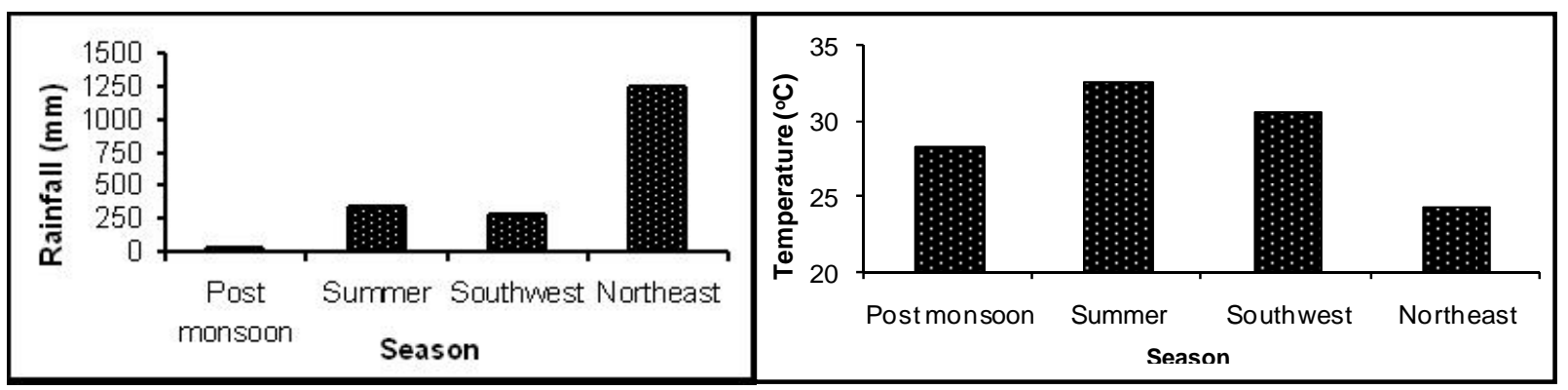

(Source: India Meteorological Department, 2008)

Figure 2 - Rainfall and Atmospheric Temperature.

\section{Salinity}

The salinity showed remarkable fluctuations with high values during the summer season. Relatively high saline values were recorded from February to September with a significant lowering during the northeast monsoon. High salinity observed in the summer might be due to high temperature and shallow nature of Palk Strait, which led to water evaporation and high salt accumulation. Thus, salinity in this coastal region varied seasonally depending upon the mixing of fresh water. Salinity exhibited negative correlations with silicate $(\mathrm{p} \geq 0.01)$ and nitrate $(\mathrm{p} \geq 0.05)$ due to rainfall, the adjoining creeks and lagoons carried large amount of fresh water into the coastal waters during the northeast monsoon season. Tables $1-4$ show the correlation matrices for different seasons.

\section{Dissolved Oxygen}

The DO values varied from 5.5 to $6.4 \mathrm{mg} / \mathrm{L}$ throughout the study period. The coastal water in the Muthupet mangrove environment was well oxygenated with DO value of $6.4 \mathrm{mg} / \mathrm{L}$ at stations 4 and 8 duirng the northeast monsoon and postmonsoon, respectively. The hike in the DO level in the northeast monsoon might be due the effect of climatic conditions such as low solar radiation prohibited by the clouds, runoff and high turbulence induced by the wave action, although the rate of photosynthesis was reduced (Kannan and Kannan 1996). However, in the mangrove environment, the dissolved oxygen level varied between 5.8 and $6.3 \mathrm{mg} / \mathrm{L}$ during the northeast monsoon season. The DO showed negative correlation with the SPM during the summer, southwest and northeast monsoon seasons.
Positive correlation with $\mathrm{pH} \quad(\mathrm{p} \geq 0.01)$ was observed during the southwest monsoon.

\section{Nitrate and Nitrite}

Not much variation was noticed in the nitrate values in the coastal water of Vedaranyam, which ranged from 0.17 to $6 \mu \mathrm{mol} / \mathrm{L}$, whereas nitrite fluctuated between 0.02 and $0.55 \mu \mathrm{mol} / \mathrm{L}$. A strong positive correlation was observed between nitrite and nitrate $(\mathrm{p} \geq 0.05)$ during the postmonsoon season. Strong negative correlation with nitrate and salinity $(\mathrm{p} \geq 0.01)$ was observed, which might be due to the less saline condition existing during the northeast monsoon. Nitrite, the intermediate oxidation state between ammonia and nitrate, can appear as a transient species by the oxidation of ammonia or by the reduction of nitrate (Sathpathy et al. 2010). Positive and negative correlation between nitrite and DO during the southwest monsoon $(\mathrm{p} \geq 0.05)$ and northeast monsoon ( $p \geq 0.01)$, respectively was due to the increased runoff resulting in declining of salinity, which led to increase in the DO and nutrient levels.

\section{Ammonia}

The possible sources of ammonia input into the waters could be from land runoff, zooplankton excretion, or demineralization of organic matter (Ketchum 1962). Ammonia level was 0.09 to 2.21 $\mu \mathrm{mol} / \mathrm{L}$ in all the seasons and did not show significant strong positive correlation $(\mathrm{p} \geq 0.01)$ with any parameter, except silicate during the northeast monsoon. A positive correlation between ammonia and nitrite $(\mathrm{p} \geq 0.05)$ observed during the northeast monsoon season might be due to the oxidation of ammonia to nitrite. 

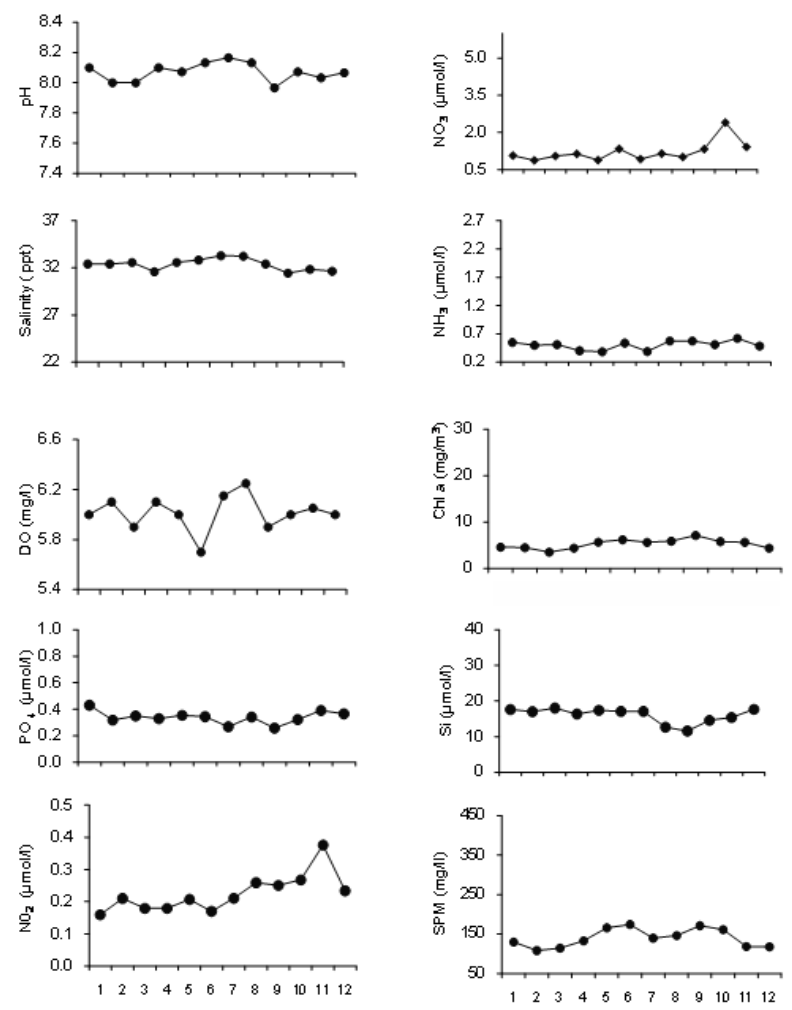

A
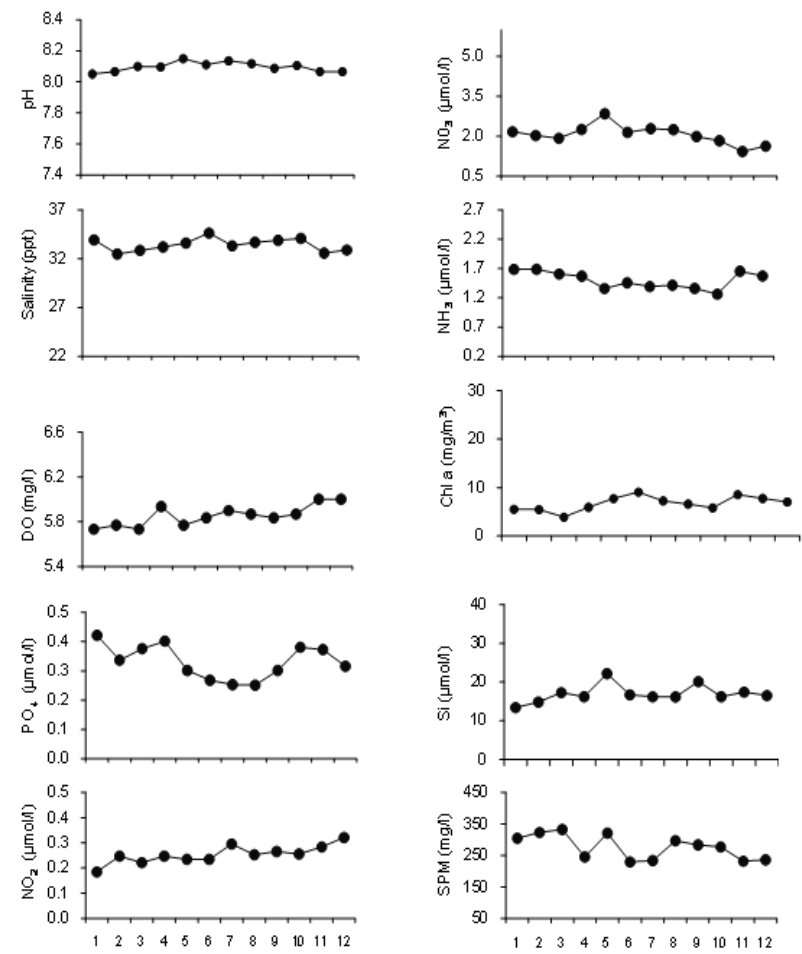

C
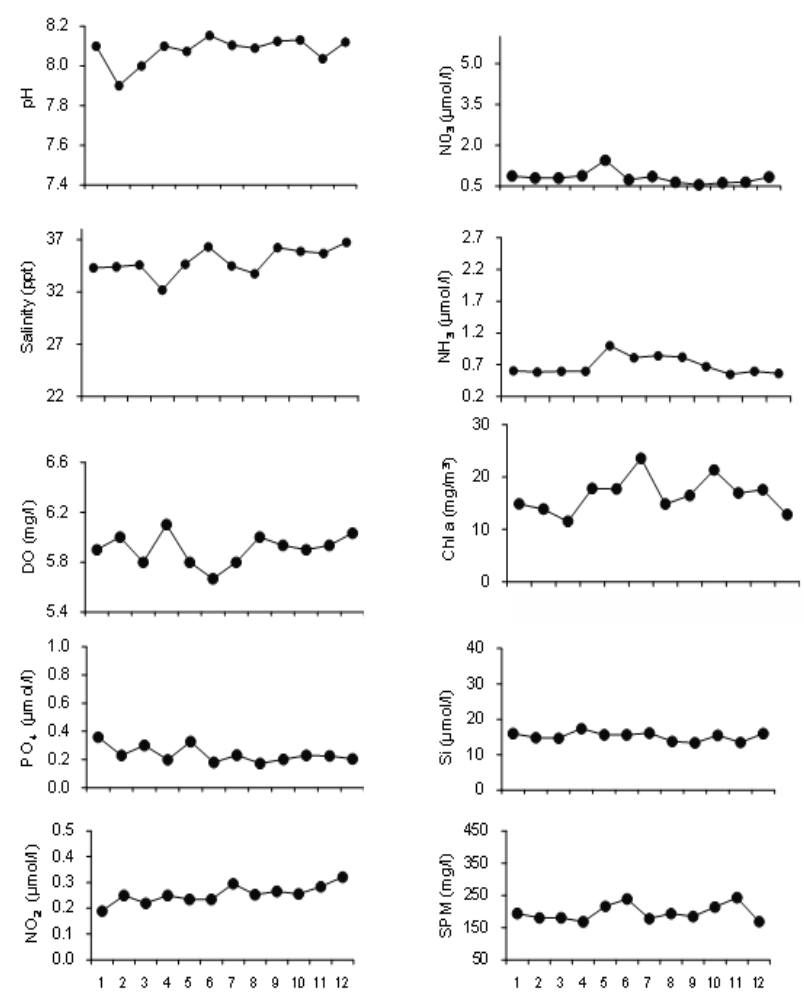

$\mathbf{B}$
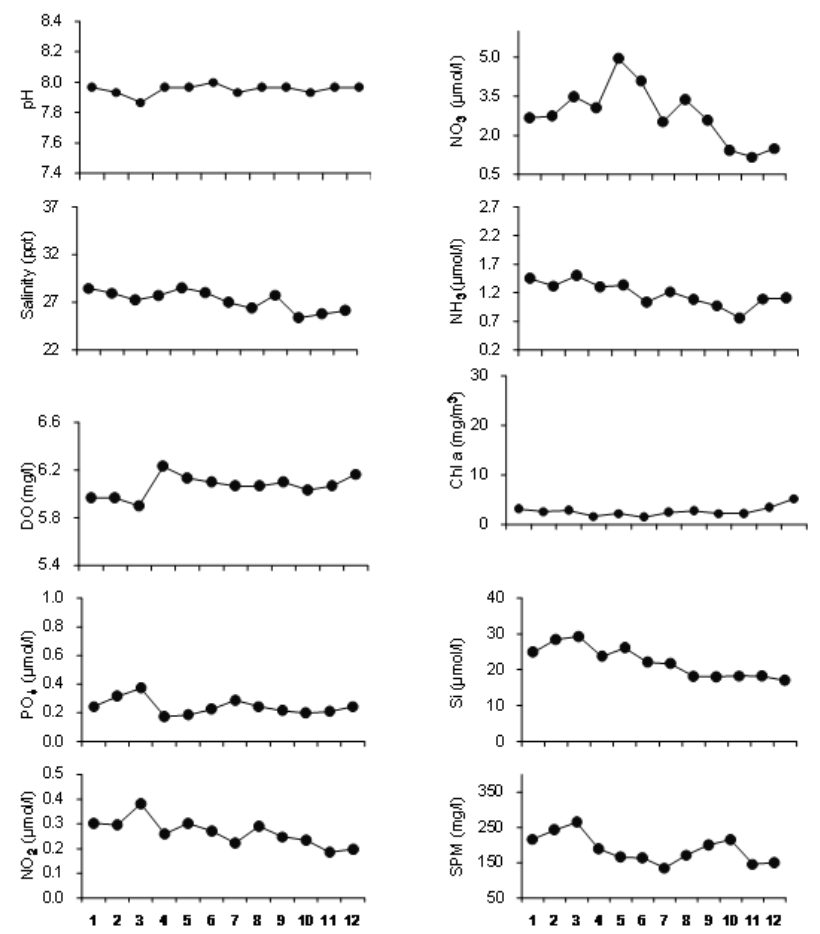

D

Figure 3 - Variations in water quality parameters (A) - Postmonsoon, (B) - Summer, (C) Southwest monsoon and (D) Northeast monsoon seasons. 


\section{Inorganic phosphate}

Estuarine mangrove waters in general have relatively low stocks of dissolved inorganic phosphorus and nitrogen (Alongi et al. 1992). Inorganic phosphate value ranged from 0.04 to $0.69 \mu \mathrm{mol} / \mathrm{L}$. In monsoon season, the runoff transported lots of terrigenous deposits to the coastal waters, the suspended sediments adsorbed to each other and settled at the bottom (Pomeroy et al. 1965). Phosphate showed negative correlation $(\mathrm{p} \geq 0.05)$ with the DO and $\mathrm{pH}$. Low phosphate levels during the northeast monsoon could be attributed to the mangrove swamps and wetlands, which trapped the land derived sediments brought in by the runoff in the monsoon season before they entered the ocean by outwelling due to the chemical and biological processes. High concentration of phosphate in the post-monsoon might be because of desorption of phosphate taking place from the sediments with increasing salinity during this period.

\section{Silicate}

Silicate concentration varied from 7.5 to 33.6 $\mu \mathrm{mol} / \mathrm{L}$. Higher concentration during the monsoon season could be ascribed to fresh water intrusion into the coastal waters and similar milieu had been reported in different coastal environments (Burton 1970). An abrupt decrease in silicate concentration observed during late post-monsoon season and summer could be due to the phytoplankton uptake, which was indicated by a strong negative correlation $(\mathrm{p} \geq 0.01)$. Strong positive correlation ( $\mathrm{p} \geq 0.01)$ with $\mathrm{pH}$ noticed during the southwest monsoon could be due to increased $\mathrm{pH}$ leading to the reduction in silicate.

\section{Suspended Particulate Matter}

SPM is one of the main forms in which various materials, including the nutrients and other pollutants are transferred from the land to marine environments. SPM concentration ranged from 88 to $390 \mathrm{mg} / \mathrm{L}$. Increase in $\mathrm{Chl}-\mathrm{a}$ values indicates elevated phytoplankton population, which contributes higher concentrations of SPM in the coastal waters. This could be proved by a strong positive correlation $(\mathrm{p} \geq 0.01)$ acquired with $\mathrm{Chl}-\mathrm{a}$ during the post-monsoon season. Similar conditions were observed in the Kalpakkam coastal waters by Sathpathy et al (2010). Negative correlation $(\mathrm{p} \geq 0.05)$ between the SPM and Chl-a was observed during the southwest monsoon.

\section{Chlorophyll a}

Chlorophyll a is considered as the most reliable index of phytoplankton biomass (Tripathy et al. 2005). Fresh water influx and land runoff resulted in low Chl-a concentration $\left(2.7 \mathrm{mg} / \mathrm{m}^{3}\right)$ at $\mathrm{S} 4$ during the northeast monsoon with decreasing salinity conditions. Marichamy et al. (1985) reported that in low saline waters $(<27 \mathrm{psu})$, high phytoplankton population could not sustain during the monsoon season. High concentration of Chl-a $\left(29.1 \mathrm{mg} / \mathrm{m}^{3}\right)$ was observed at S6 (Table 2) in summer season, which could be due to increase in temperature, salinity and high concentration of nutrients carried into these environments stimulating a rich phytoplankton growth. In general, Chl-a values were high near the Muthupet mangroves compared to Point Calimere. Increase in the salinity and temperature during the summer season resulted in higher $\mathrm{pH}$ values, which in turn increased the Chl-a due to higher photosynthetic activity by the phytoplankters. This was confirmed from a positive correlation $(\mathrm{p} \geq 0.01)$ for $\mathrm{pH}$ and Chl-a.

Table 1 - Correlation matrix - post monsoon.

\begin{tabular}{lcccccccccc}
\hline \multicolumn{1}{c}{} & $\mathbf{p H}$ & Salinity & DO & Chl a & NO2 & NO3 & NH3 & PO4 & Si & SPM \\
\hline pH & 1 & & & & & & & & & \\
Salinity & .27 & 1 & & & & & & & \\
DO & .19 & .17 & 1 & & & & & & \\
Chl a & .10 & .25 & -.20 & 1 & & & & & & \\
NO2 & -.32 & -.26 & .30 & .37 & 1 & & & & & \\
NO3 & -.31 & -.41 & -.03 & .06 & $.76^{* *}$ & 1 & & & & \\
NH3 & $-.58^{*}$ & -.01 & -.14 & .28 & .50 & .55 & 1 & & & \\
PO4 & -.09 & -.24 & -.05 & -.45 & .00 & .43 & .25 & 1 & & \\
Si & .20 & -.05 & -.18 & $-.72^{* *}$ & -.50 & -.06 & -.49 & .46 & 1 & \\
SPM & .30 & .22 & -.44 & $.81^{* *}$ & -.06 & -.23 & -.03 & -.37 & -.46 & 1 \\
\hline
\end{tabular}


Table 2 - Correlation matrix - summer.

\begin{tabular}{lcccccccccc}
\hline & pH & Salinity & DO & Chl a & NO2 & NO3 & NH3 & PO4 & Si & SPM \\
\hline pH & 1 & & & & & & & & & \\
Salinity & .19 & 1 & & & & & & & \\
DO & -.40 & -.38 & 1 & & & & & & \\
Chl a & $.58^{*}$ & .23 & -.39 & 1 & & & & & & \\
NO2 & -.08 & .25 & .44 & -.16 & 1 & & & & \\
NO3 & .05 & -.29 & -.21 & -.15 & -.39 & 1 & & & \\
NH3 & .41 & -.09 & -.57 & .35 & -.53 & .55 & 1 & & \\
PO4 & -.19 & -.17 & -.23 & -.38 & -.41 & $.63^{*}$ & .07 & 1 & & \\
Si & .31 & -.39 & .03 & -.15 & -.15 & .46 & -.00 & .18 & 1 & \\
SPM & .20 & .38 & $-.59^{*}$ & .56 & .05 & -.01 & .27 & .03 & -.32 & 1 \\
\hline
\end{tabular}

Table 3 Correlation coefficient - southwest monsoon.

\begin{tabular}{|c|c|c|c|c|c|c|c|c|c|c|}
\hline & pH & Salinity & DO & Chl a & NO2 & NO3 & NH3 & PO4 & $\mathbf{S i}$ & SPM \\
\hline pH & 1 & & & & & & & & & \\
\hline Salinity & .08 & 1 & & & & & & & & \\
\hline DO & -.15 & -.27 & 1 & & & & & & & \\
\hline Chl a & .22 & .48 & .50 & 1 & & & & & & \\
\hline NO2 & -.21 & -.34 & $.83^{* *}$ & .28 & 1 & & & & & \\
\hline NO3 & $.68^{*}$ & .37 & -.44 & .01 & -.44 & 1 & & & & \\
\hline NH3 & -.30 & $-.61 *$ & -.14 & -.52 & -.21 & -.34 & 1 & & & \\
\hline PO4 & -.17 & -.26 & -.20 & -.37 & -.38 & -.32 & .53 & 1 & & \\
\hline $\mathbf{S i}$ & $.72 * *$ & .10 & .01 & .18 & .12 & .34 & -.51 & -.34 & 1 & \\
\hline SPM & .36 & -.11 & $-.70 *$ & $-.58^{*}$ & $-.61^{*}$ & .37 & .09 & .21 & .12 & 1 \\
\hline
\end{tabular}

Table 4 - Correlation coefficient - northeast monsoon.

\begin{tabular}{lcccccccccc}
\hline \multicolumn{1}{c}{ pH } & Salinity & DO & Chl a & NO2 & NO3 & NH3 & PO4 & Si & SPM \\
\hline pH & 1 & & & & & & & & & \\
Salinity & .20 & 1 & & & & & & & \\
DO & $.64^{*}$ & -.08 & 1 & & & & & & \\
Chl a & .10 & -.42 & .14 & 1 & & & & & \\
NO2 & -.23 & -.55 & $-.65^{*}$ & -.31 & 1 & & & & \\
NO3 & .17 & $-.72^{* *}$ & -.08 & -.53 & $.68^{*}$ & 1 & & & \\
NH3 & -.09 & -.56 & -.30 & .07 & $.66^{*}$ & .41 & 1 & & \\
PO4 & $-.66^{*}$ & .07 & $-.66^{*}$ & .19 & .53 & .06 & .49 & 1 & & \\
Si & -.38 & $-.66^{*}$ & -.55 & -.29 & $.79^{* *}$ & .56 & $.81^{* *}$ & .53 & 1 & \\
SPM & -.47 & .24 & $-.77^{* *}$ & -.18 & $.73^{* *}$ & .09 & .38 & .51 & $.61^{*}$ & 1 \\
\hline
\end{tabular}

*Correlation is significant at the 0.05 level. $\quad * *$ Correlation is significant at the 0.01 level.

\section{Principal Component Analysis (PCA) Post Monsoon Season}

The PCA of the water quality parameters during the post-monsoon season showed four components with Eigen values higher than 1 and $83.39 \%$ total variance (Table 5). The first principal component (PC 1), explaining about $29.97 \%$ variance showed possible utilization of silicate by the phytoplankton for photosynthetic activity. This was indicated by the positive loadings for chl-a and negative for silicate. This revealed that the strong loadings of nitrite could be possible by the oxidation of organically derived ammonia. The second principal component (PC 2, 27.4\% variance) was related to the inputs of phosphate to the coastal water by monsoonal runoff. The third principal component (PC 3) showed that the increase in the salinity led to increases in the $\mathrm{pH}$ exhibiting their positive loadings. The fourth principal component (PC 4 for $12.54 \%$ variance) showed as inverse relationship between the DO and SPM through the positive loading for DO and negative for SPM. 


\section{Summer Season}

Three factors were developed for the summer season with Eigen values higher than 1, with $72.21 \%$ total variance (Table 6). First principal component (PC 1, 33.9\% variance) explained the release of ammonia by the microbial activity through the utilization of dissolved oxygen from the positive loadings for ammonia and negative loading for the DO. The second principal component (PC 2, 25.14\% variance) depicted positive loading for the salinity and negative loadings for the DO, indicating that when salinity increased, the DO in the coastal water decreased. The third principal component (PC 3, 13.15\% variance) elucidated the utilization of phosphate by the phytoplankton for photosynthetic activity.

Table 5 - Factor analysis - post monsoon.

\begin{tabular}{lcccc}
\hline Parameters & $\mathbf{1}$ & $\mathbf{2}$ & $\mathbf{3}$ & $\mathbf{4}$ \\
\hline pH & -0.22 & 0.07 & 0.85 & 0.00 \\
Salinity & 0.06 & -0.16 & 0.63 & 0.04 \\
DO & 0.14 & -0.00 & 0.27 & 0.93 \\
NO2 & 0.80 & 0.27 & -0.24 & 0.30 \\
NO3 & 0.47 & 0.64 & -0.42 & 0.06 \\
NH3 & 0.64 & 0.25 & -0.45 & -0.12 \\
PO4 & -0.23 & 0.88 & -0.19 & -0.01 \\
Si & -0.85 & 0.39 & -0.00 & 0.00 \\
SPM & 0.38 & -0.25 & 0.46 & -0.71 \\
Chl a & 0.77 & -0.20 & 0.35 & -0.44 \\
Eigen values & 3.29 & 3.01 & 1.48 & 1.38 \\
\% of variance & 29.97 & 27.40 & 13.47 & 12.54 \\
Cumulative \% & 29.97 & 57.37 & 70.84 & 83.39 \\
\hline
\end{tabular}

Table 6 - Factor analysis - summer.

\begin{tabular}{lccc}
\hline Parameters & $\mathbf{1}$ & $\mathbf{2}$ & $\mathbf{3}$ \\
\hline pH & 0.19 & 0.00 & 0.83 \\
Salinity & -0.19 & 0.70 & 0.14 \\
DO & -0.58 & -0.60 & -0.27 \\
NO2 & -0.72 & 0.02 & -0.00 \\
NO3 & 0.86 & -0.27 & -0.12 \\
NH3 & 0.73 & 0.14 & 0.39 \\
PO4 & 0.64 & 0.01 & -0.60 \\
Si & 0.33 & -0.72 & 0.22 \\
SPM & 0.19 & 0.77 & 0.24 \\
Chl a & 0.08 & 0.39 & 0.79 \\
Eigen values & 3.73 & 2.76 & 1.44 \\
\% of variance & 33.90 & 25.14 & 13.15 \\
Cumulative \% & 33.90 & 59.05 & 72.21 \\
\hline
\end{tabular}

\section{Southwest Monsoon Season}

The PCA analysis of the coastal water extracted three components with Eigen values higher than 1, with $78.54 \%$ total variance (Table 7). The first principal component (PC 1, 33.06\% variance) indicated possible utilization of nitrate by the phytoplankton. This was demonstrated by the positive loadings for chlorophyll a and negative for nitrate. The second principal component (PC 2, $29.47 \%$ variance) related the inputs of nutrients such as ammonia and phosphate from the runoff influenced by the pre-monsoon showers. This was indicated by the loadings, which were negative for the salinity and positive for ammonia and phosphate. The third principal component (PC 3, $16 \%$ variance) pointed out an increase in chlorophyll a with high salinity conditions. Further, it revealed possible utilization of ammonia for the phytoplankton production. 


\section{Northeast Monsoon Season}

During the northeast monsoon, three components were extracted with Eigen values higher than 1, with $81.98 \%$ total variance (Table 8). First principal component (PC 1, 46.42\% variance) related to the inputs of nutrients by the monsoonal runoff during the northeast monsoon. This was signified by the loadings, which was negative for the salinity and positive for inorganic nutrients.
The second principal component (PC 2, 24.57\% variance) exhibited the regeneration of phosphate with DO utilization by the microorganism to liberate phosphate to the coastal waters. This was observed from the positive loading for phosphate and negative for the DO. The third principal component (PC 3, explaining 10.98\% variance) showed the utilization of nitrate by the phytoplankton.

Table 7 - Factor analysis - southwest monsoon.

\begin{tabular}{lccc}
\hline Parameters & $\mathbf{1}$ & $\mathbf{2}$ & $\mathbf{3}$ \\
\hline pH & -0.19 & 0.06 & 0.10 \\
Salinity & -0.36 & -0.48 & 0.76 \\
DO & 0.93 & 0.03 & 0.12 \\
NO2 & 0.93 & -0.21 & -0.17 \\
NO3 & -0.53 & -0.33 & 0.10 \\
NH3 & -0.10 & 0.71 & -0.40 \\
PO4 & -0.27 & 0.82 & 0.01 \\
Si & 0.10 & -0.19 & -0.01 \\
SPM & -0.73 & 0.03 & -0.45 \\
Chl a & 0.43 & -0.16 & 0.80 \\
Eigen values & 3.63 & 3.24 & 1.76 \\
\% of variance & 33.06 & 29.47 & 16.00 \\
Cumulative \% & 33.06 & 62.53 & 78.54 \\
\hline
\end{tabular}

Table 8 - Factor analysis - northeast monsoon.

\begin{tabular}{lccc}
\hline Parameters & $\mathbf{1}$ & $\mathbf{2}$ & $\mathbf{3}$ \\
\hline pH & 0.19 & -0.82 & 0.13 \\
Salinity & -0.81 & -0.01 & -0.03 \\
DO & -0.09 & -0.91 & 0.04 \\
NO2 & 0.67 & 0.62 & 0.06 \\
NO3 & 0.88 & -0.01 & -0.21 \\
NH3 & 0.68 & 0.32 & 0.56 \\
PO4 & 0.08 & 0.78 & 0.40 \\
Si & 0.75 & 0.57 & 0.12 \\
SPM & 0.19 & 0.83 & -0.00 \\
Chl a & -0.43 & -0.11 & 0.83 \\
Eigen values & 5.10 & 2.70 & 1.20 \\
\% of variance & 46.42 & 24.57 & 10.98 \\
Cumulative \% & 46.42 & 71.00 & 81.98 \\
\hline
\end{tabular}

\section{CONCLUSIONS}

The hydrological parameters exhibited distinct variations in two different zones along the coastal waters of Point Calimere and Muthupet. High salinity value (39.2 psu) was observed along the Palk Strait during summer, which could be due to high temperature and shallow nature of the study area. The runoff during the northeast monsoon reduced the salinity where large amount of fresh water entered into the coastal waters from the adjoining wetlands. High DO values around 6.4 $\mathrm{mg} / \mathrm{l}$ during the northeast monsoon could be attributed to low temperature and higher wave action dissolving much of atmospheric air.

Low concentrations of nutrients during then monsoon observed at the stations dominated by the mangroves could be attributed to the mangrove 
swamps and wetlands, which trapped land derived sediments brought in by the runoff in the monsoon season before they entered the ocean by outwelling due to chemical and biological processes. A marginal increase in chlorophyll a was observed during the post- monsoon and maximum concentration was observed in summer, which could be due to dominant saline conditions prevailing during that period.

The water quality forms the basis for the floral and faunal diversity of the mangrove ecosystems. The results from this study could be used for a better water quality management of Vedaranyam wetland and the coastal zone. The conservation, management and sustainable development of the Vedaranyam swamp would depend on the maintenance of the hydrological characteristics without much alteration.

\section{REFERENCES}

Alongi DM, Christoffersen P. Nitrogen and Phosphorous cycles Tropical mangrove ecosystems. American Geophysical Union, Washington: D.C; 1992.

APHA. Standard methods for the examination of water and wastewater. 19th ed. Published by the American Public Health Association. Washington: DC; 1995.

Burton JD. The behavior of dissolved silicon during estuarine mixing, preliminary investigations in the Vellar estuary. J Cons Int Explor. 1970; 33: 141-148.

Cloern JE. Our evolving conceptual model of the coastal eutrophication problem. Mar Ecol Prog Ser. 2001; 210: 223-253.

Clough BF. Primary productivity and growth of mangrove forests. Tropical mangrove ecosystems. In Robertson AI, Alongi DM (ed.), American Geophysical Union, Washington: D.C; 1992.

Grasshoff K, Erhardt M, Kremblig K. Methods of sea water analysis. 2nd edition. New York and Weinheim: Germany; 1983.

Iyer CSP, Sindhu M, Kulkarni SG, Tambe SS, Kulkarni BD. Statistical analysis of the physico-chemical data on the coastal waters of Cochin. J Environ Monitor. 2003; 5(2): 324-327.

Kannan R, Kannan L. Physicochemical characteristics of seaweed beds of the Palk Bay, Southeast coast of India. Ind J Mar Sci. 1996; 25: 358-362.

Ketchum BH. Regeneration of nutrients by zooplankton. Rapports ET Process - verbaux des
Reunion. Conseil. Int Pour 1 Explor De la mer.1962; 153:142-147.

Kress N. Coto S. Brenes C. Horizontal transport and seasonal distribution of nutrients, dissolved oxygen and chlorophyll-a in the Gulf of Nicoya, Costa Rica: a tropical estuary. Continental Self Research. 2002; 22: 51-66.

Marichamy R, Gopinathan CP, Sirameetan P. Studies as primary and secondary production in relation to hydrography in the inshore waters of Tuticorin. $J$ Mar Biol Asso India. 1985; 27: 129-137.

Martin JM, Windom HL, Mantoura RFC, Martin JM, Wollast R. Present and future roles of ocean margins in regulating marine biogeochemical cycles of trace elements. Ocean Margin Processes in Global Change. John Wiley \& Sons: Chichester; 1991.

Ntengwe FW. Pollutant loads and water quality in streams of heavily populated and industrialised towns. Physics and Chemistry of the Earth. 2006; 31: 832-839.

Parsons RT, Maita Y, Lalli CM. A Manual of Chemical and Biological Methods of Seawater Analysis. Pergamon Press; 1984.

Pomeroy LR, Smith EE, Grant CM. Exchange of phosphate between estuarine waters and sediments. Limnology and Oceanography. 1965;10: 167-172.

Rutner F. Fundamentals of Limnology. Univ. Toronto press: Toronto; 1966.

Satpathy KK, Mohanty AK, Gouri Sahu, Sarkar SK, Natesan U, Venkatesan R, Prasad MVR. Variations of physicochemical properties in Kalpakkam coastal waters, east coast of India, during southwest to northeast monsoon transition period. Environmental Monitoring and Assessment [Internet] 2010; 171: 411-424. Available from: www.springerlink.com/index/3t12m1j0025086r1.pdf

Scialabba N. Integrated coastal area management and agriculture, forestry and fisheries. FAO guidelines. Environment and Natural Resources Service, FAO: Rome; 1998.

Tripathy SC, Ray AK, Paatra S, Sarama VV. Water quality assessment of Gautami-Godavari mangrove estuarine ecosystem of Andhra Pradesh, India during September 2001. J Earth Syst Sci. 2005; 114: 185190.

Viles H, Spencer T. Coastal problems: Geomorphology, Ecology and society at the coast. Edward Arnold: Great Britain; 1995. 